\title{
Grammatical Error Found in the Academic Essays Written by Students of English Education
}

\author{
Zuvyati A. Tlonaen \\ Universitas Kristen Artha Wacana, Kupang \\ E-mail:zuvyatitlonaen@ukaw.ac.id
}

\begin{abstract}
Writing academically demands students to use correct grammar yet students still make error grammatically. This research reports on grammatical errors in academic essays written by Students of English Education. This study addresses two research questions; 1) What are the grammatical errors made by Students of the English Education Program? 2) From the error classification, what is the major error made? The method used is a qualitative method. The sample subjects were 5 of 15 students writing the essays. They are fifth semester students from English Education study program, Artha Wacana Christian University, Kupang. The samples were determined by purposive sampling. Data was collected using documentation techniques. The results indicated that students have made the grammatical errors in their academic essays. The errors committed by the students are; 1) noun-noun groups, this part consists of four categories, students made error in all categories; 2) Verb-verb groups, this part has nine categories; students committed errors in three categories; 3) Preposition error, this part has three categories. Students made errors in two categories; 4) Sentence structure; this part consists of eight categories. Students made errors in three categories. The major errors committed by the students are; first, in noun-noun groups by using inappropriate combination of subject and verb agreementand omitting the plural marker $-s$; second, in verb-verb groups in which the errors are mainly in the omission of suffix $-s$, -es, -ed and the omission of auxiliary verbs. Thus, students of English education need to improve their writing on academic essays.
\end{abstract}

Keyword: Grammatical error, academic essay, students of English Education

\section{Kesalahan Tata Bahasa yang Ditemukan di Esai Akademik yang Ditulis oleh Siswa Pendidikan Bahasa Inggris}

\begin{abstract}
Abstrak
Tulisan yang bersifat akademik menuntut mahasiswa menulis dengan menggunakan tata bahasa yang benar namun mahasiswa masih sering melakukan kesalahan gramatikal. Penelitian ini melaporkan tentang eror dalam tata bahasa dalam esai akademik yang ditulis oleh mahasiswa Pendidikan Bahasa Inggris. Penelitian ini membahas dua pertanyaan penelitian; 1) Kesalahan tata bahasa yang dilakukan oleh mahasiswa pendidikan Bahasa Inggris? 2) Dari klasifikasi eror, eror apa yang paling banyak dilakukan? Metode yang digunakan adalah metode kualitatif. Subjek sampel adalah 30 mahasiswa semester lima dari program studi pendidikan bahasa Inggris, Universitas Kristen Artha Wacana Kupang. Sampel ditentukan secara purposive sampling. Data dikumpulkan dengan menggunakan teknik dokumentasi. Hasil penelitian menunjukkan
\end{abstract}


bahwa eror dalam tata bahasa yang ditemukan dalam esai yang ditulis oleh mahasiswa Pendidikan Bahasa Inggris. Kesalahan yang dilakukan oleh mahasiswa adalah; 1) kelompok kata benda, bagian ini terdiri dari empat kategori, mahasiswa membuat kesalahan pada semua kategori; 2) Grup kata kerja, bagian ini memiliki Sembilan kategori; mahasiswa melakukan eror dalam tiga kategori; 3) Kesalahan preposisi, bagian ini memiliki tiga kategori. Mahasiswa membuat kesalahan pada dua kategori; 4) Struktur kalimat; bagian ini terdiri dari delapan kategori. Mahasiswa membuat kesalahan dalam tiga kategori dengan menggunakan kalimat campur aduk atau tidak logis, menggunakan kata hubung yang tidak sesuai. Kesalahan utama yang dilakukan oleh mahasiswa adalah; pertama, dalam kelompok kata benda dengan menghilangkan tanda jamak -s dan menggunakan kombinasi subjek dan kata kerja yang tidak sesuai; kedua, dalam kelompok kata kerja-kata kerja di mana kesalahan utamanya adalah dalam penghilangan akhiran -s, -es, -ed, dan penghilangan kata kerja bantu. Dengan demikian, mahasiswa program studi bahasa Inggris memerlukan perbaikan dalam menulis akademik esai untuk mencapai tulisan yang sesuai dengan tata bahasa yang benar.

Kata kunci: Eror tatabahasa, esai akademik, mahasiswa pendidikan bahasa Inggris

\section{INTRODUCTION}

Writing an essay is very common in academic life, particularly in the university level. In this stage, students are demanded to write academic writing. One of many tasks students do is writing an essay. Why writing is the most important thing for students? Because writing is one of many ways of being assessed (Pratama, 2017). Thus, every student is demanded to master academic writing skills. When students write their paper academically, they are systematically constructing their ideas, selecting appropriate words based on the context of the language in order to be understood by the readers (lecturers, teachers or assessors) (Pratama, 2017; Andrian, 2015).

Skills such as choosing appropriate words and correct usage of grammar (English structure regulation) are highly needed. Besides having analytical and critical thinking or ideas, being good at mastering the writing regulation or setting critical argument, students must have standard of grammar. In fact, most EFL students are still struggling difficulties to write academically. Brown in Pratama (2017), discussed several characteristics of written languages; "the writer must learn how to remove redundancy, how to combine sentences, how to make references to other elements in the text, how to create syntactic and lexical variety, and much more".

Concerning the complexity in academic writing, there are numbers of errors and mistakes inevitably produced by English language learners in written language (also in spoken language) so that many researchers are interested to conduct the research on error analysis in students' writing (Mehdi, 2018). Many aspects can be the cause of errors and mistakes in writing, one of those could be the intervenes of mother tongue (Keshavards, 2012; Putri, 2014; Amara, 2015). Sometimes, the English learners construct English sentences based on our mother tongue. English has its own rules and indeed, defferent from the rules of the mother tongue.

The distinction between both error and mistake is that mistake refers to someone is aware of making mistakes because she/he has the knowledge of language structure while error refers to someone is not aware of the mistakes 
and needs additional knowledge on language learning. What can be inferred from the difference is that error is more serious and requires more treatments than mistake because mistake does need a special treatment yet can be selfcorrected. Self-correction is one of correction techniques besides teacher correction, peer correction, and group correction (Zublin, 2015). Whereas error that refers to structures cannot be corrected by self (Amara, 2015) because it is unconsciously done by learners and error is "systematic" (Andrian, 2015). Errors might need peer correction or teacher correction. This is the reason why teachers and researchers are urged to have deep insight into error analysis for they have the responsibility to locate the errors made by learners who do not locate them.

Grammar has a very strong relation with sentence, and EFL students, aforementioned previously, are struggling to that. It is not only, students in the level of schools make an error in grammar but also the undergraduate even the postgraduate students. Numbers of studies found that grammar still becomes the major problem in writing. Research conducted by Maspufa (2019) and Hamzah (2012) have shown that grammatical errors are made by the eight-semester students and the first semester students. Research conducted by Imani \& Habil (2012) revealed that grammaticality is one of the common challenges faced by NNS postgraduate students. A grammatical error has been found also in Iraqi postgraduate students' academic writing in which the study indicated that postgraduate students committed errors in tenses, prepositions, passive voice, verb and morphological errors (Mohammed, 2015). Those studies show that EFL students in the worldwide made error in their academic writing. Therefore, this case is very interested to be studied for the reasons is that English has been studied for a few years, however, EFL students still unconsciously make an error in grammar more often.

Based on several issues on grammatical error in writing and on the reason stated above, this article intends to identify the grammatical error in the academic essays written by students of English education study program since all university students, particularly students learning English, deal with academic writing in all their projects. The task given is to write essays. The students, of course, experienced problems with grammaticality. Therefore, this research aims to find out the errors that the students made in their academic essays and to see the major errors they deal with.

\subsection{Error}

To understand errors, we need to know the difference between errors and mistakes. Keshavarz (2012) stated that errors are"considered to be systematic, governed by rule, and appear because a learner's knowledge of the rules od the target language is incomplete". In other words, error refers to students' mistakes in terms of understanding. Thus, the error shown here is not because students experience technical factors such as 'slip of the tongue' but the error that appears here is an error that illustrates that students have not recognized, known, and understood the language patterns used. In contrast to errors, mistakes are "random deviation, unrelated to any system, and instead representing the sampe types of performance mistakes that might occur in the speech or writing of native speakers such as slips of the tongue, and the like" (Kezhavards, 2012; Amara, 2015; Yang, 2010).

Student mistakes based on false assumptions or failure to use certain 
systems that are already known. This means students actually already recognize, know and understand certain patterns in using the language that will be used. However, due to the 'slip of the tongue' factor, irregular grammar, errors in remembering, or even physical factors such as fatigue and uncontrolled emotions. Someone especially those who learn languages can correct their mistakes if they gain additional knowledge on topics relating to language learning. Therefore, the error analysis should be conducted to make corrections.

\subsection{Grammar}

Grammar has been a compulsory subject at the university level both undergraduate and postgraduate programs. EFL Learners are expected to construct the sentence based on the rules of English or structurally correct sentences. Once grammar is mentioned, we lead our thinking to the elements of grammar, such as noun phrase (NP), verb phrase (VP), Prepositional phrase (PP), adverb, adjective and other English grammar units. Grammar is about sentences (Yule, 2010).

Grammatical sentences are what the learners are trying to learn at first, they learn how to insert the words (lexis) they had learned to make more and more sentences. In making sentences, learners may start with grammar. Grammar is about words, Booij (2012) in his book 'The Grammar of Words' linked grammar to a more specific study of Linguistic morphology in which grammar is broken down into very specific items such as word formation; derivational, compounding words and inflection with the smaller unit within the words.

Besides, grammar is linked to linguistic morphology; grammar also engaged syntax (Yule, 2017). Yule (2010; 2017) mentioned that Syntax and morphology are the subdivision of grammar. They are different in focus areas yet interrelated areas of study. Morphology refers to the study of how words are formed out of smaller units (called morphemes) or "the study of forms" (Carnie, 2013; Yule, 2017) and syntax is that the study of how phrases and sentences are structured out of words or it concentrates on structure and how to order the phrases or sentences (Carnie, 2013; Yule, 2017). Language can be said that constructed by the very smaller unit of words. Therefore, grammar cannot be inseparable from words and sentence, and language.

Grammar is such an important thing to apply in learning a language (Putri, 2014). Grammar is a set of structured rules that arrange sentences, phrases and words in any language. Every language has its grammar. There are numbers of scientific researchers investigating structures in their languages, the mother tongue or vernacular languages. I tells us that study how to generate a language is important. Concerning grammar, Canie (2013) states that grammar is "the set of rules that generate a language". If we write or speak phrases or sentences, we are structuring them to be understood then we are forming language Students, when writing or speaking their task, are applying grammar. The grammar used must be correct and complete so that it is understanable in order to avoid the missunderstanding because sentences are in disorder. Grammar is highly important in academic writing because it helps readers easy to read. It helps the writers to craft words into coherent sentences and how to form sentences into paragraph so that the writing successfully convey the meanings 
intended by the writers. Students who are able to use correct grammar could probably produce successful writing leading them to have a good grade from teachers.

Every language has its own grammar rules. To construct meaningful sentence and can be understood or delivered well, students should have competency in using grammar correctly. Language learners who use the rule of grammar correctly either in writing or speaking, particular in writing as a productive skill required by university students, will produce good products of writing. However, EFL undergraduate students, even though they have learned English more or less 16 years; 6 years in Elementary schools, 3 years in Junior high school so does in Senior High School, and 4 years in university focusing on English language teaching, are still unconsciously make grammatical error in their writing.

Grammatical error is simply defined as an error in which the grammar rules is used incorrectly or there is a deviation of language grammatical rules (Amara, 2015). Concerning to writing, grammatical error is the faulty that might cause meaning delivered in written discourse unclear, make the readers are diffucult to understand the message or cause on the students' results. Putri (2014) strengthened by stating learners should give much attention the grammatical errors they have made in their writing as it affects their successful in academic writing.

\subsection{Taxonomy of Grammatical Error}

Ho (in Putri, 2015) categorized taxonomy of grammatical errors that contain part of speech into there are four taxonomies of errors; errors regarding noun and noun groups, error regarding verbs and verbs groups, error regarding preposition and error regarding sentence structure. Errors regarding noun-noun groups consist of four categories. There are 1) unnecessary insertion/overgeralization of plural maker $-\mathrm{s}, 2$ ) omission of plural maker $-\mathrm{s}$ (under-marking of plural), 3) inappropriate selection/usage of quantifier/article determiner, and 4) the last is inappropriate combination of subject and verb. The error in verb-verb groups consists of nine categories; they are 1) omission of suffix -s/ -es/ -ed/ing, 2) omission of $-e d$ participle after a form of the verb be, 3) inappropriate form after modal verb (unnecessary insertion/overgeneralization of suffix $-s$, -ed, -ing, 4) inappropriate form after modal verb (omission of suffix $-e d$, passive form), 5) omission of direct object, 6) omission of infinitives to, 7) omission of -ing participle, 8) omission of auxiliary verb, and 9) inversion of verb-subject in indirect question format. The prepositions errors consist of three categories. They are 1) omission of preposition, 2) unnecessary insertion of preposition, 3) and inappropriate selection of usage preposition. Besides that, the errors regarding sentence structure consists of eight categories. They are 1) dangling modifier, 2) squinting modifier, 3) jumbled-up or illogical sentences, 4) incomplete or fragmented sentences, 5) run-on sentence, 5) inappropriate coordinating conjunction, 7) inappropriate subordinating conjunction, and 8) inappropriate combination of conjunction".

\section{METHOD}

This research used qualitative descriptive method. Therefore, researcher descriptively classified the grammatical error made by the research respondents. Research populations are 1 class of fifth semester students of English Education study program, Artha 
Wacana Christian University, Kupang. Samples involved were 15 students determined by purposive sampling. However, by seeing the same error written by the students and there are 20 essays, researcher, therefore, chose only 5 students essays as the samples to be presented in this article. To collect the data, researcher used documentary technique. The data were the students' mini essays around 500-700 words. The essays taken as samples were 10 essays written by 5 students. The researcher gave the students the same topics. Students wrote the essays twice in different meeting.

Researcher did not conduct a more complex data collection such as interview or observation. The data were analyzed using Miles, Huberman \& Saldana (2014) model including data collection, data display, data reduction and data verification and for the data classification of the errors, the researcher used Taxonomy of grammatical error adapted from Ho (2005).

\section{FINDINGS AND DISCUSSION}

To answer the research questions on what are the grammatical errors that students commit in their writing production, the researcher analyzed the data collected using Ho (2005) taxonomy of grammatical error. The analysis also uses the main source of grammar form Azar \& Hagen (2017) Murphy (2019) \& Boojars \& Burridge (2010).

\section{Grammatical Error Made by Students' of English Education}

Based on Ho's taxonomy of grammatical errors (in Putri, 2014), students of English Education made errors as follows:

\section{Noun-Noun Groups}

1) Unnecessary insertion of plural maker-s

Sentence 1: Linguistics consequences has three stands.

Sentence 2: Those kinds of questions may become a main questions

In sentence 1, the word 'linguistics' in the sentence above is noun which means the scientific study of language and its sturucture, including the study of grammar, syntax, phonetics or the specific branches of linguistics. The word 'consequences' is plural noun that means more than one consequences. But in the context of the sentence, the word 'linguistics' should be in the form of adjective 'linguistic' which functions as a noun complement for 'consequences'. Therefore, adding ' $s$ ' is unnecessay. The correct phrase, based on the sentence context, is 'linguistic consequences' meaning that there are more than one consequences relating to linguistics.

In sentence 2, the word 'questions' is in plural form. It does not mean that using ' $\mathrm{s}$ ' in that word is incorrect or correct. However, if we look at the noun phrases ' $a$ main questions', the article 'a' (determiner) is singular marker used with singular countable nouns. If the writer of the essay intends to state more than one question, then she can not use the article ' $a$ ' and ' $s$ ' is added but if the writer intends to have only one main question, then ' $s$ ' is not necessary. Therefore, if we refer to the sentence context above ' $s$ ' is unnecessary.

\section{2) Omission of plural maker $-s$}

Sentence 1: "including historical relation of Britain's value and institutions"

Sentence 2: "...whether faculty or courses and so forth. People who want to go travelling can easily find a flight 
schedule, ticket price and indeed pay the ticket in online".

Sentence 3: Even English is not spoken as first language in all the country.

Sentence (s) 4: ...such as America, Australia and New Zealand. Even in some countries, such as Australia and New Zealand, some language tribes feel underestimate by the coming of English language.In these country, religion and social well-being play most in the development of the language rather than the politics.

Sentence 5: ..so many regionhave used English.

In sentence 1, thewords 'value' and 'institution' are nouns. The writer of the essay wrote one of the noun with singular and another with plural marker $s$. If the writer intended to state that Britain has more than one value then suffix $-s$ must be added to the word 'value'. It becomes 'values' to be parallel with the noun 'institutions'. Based on the context of the sentence, Britain has more than one value so that adding suffix -sin the noun 'value' is required.

Sentence 2 shows the same error as sentence 1 , the word 'faculty' must be in plural form 'faculties'to be parallel with courses. It can be seen from the context of the sentence that the writer looked for more than one faculty so that adding suffix '-es' in 'faculty-faculties' is required. Sentence 3: the noun 'country' should be written in plural form 'countries'due to the modifier 'all' referring to the whole particular group, then the noun 'country' should be added '-es' by the chance of ' $y$ ' with ' $i$ ' and placing 'es' so that the noun becomes plural noun 'countries".

In sentence (s) 4 (similar to sentence 3), the error is found in noun phrase 'in these country'. the researcher presents the complete sentences so that we can see the entire context. The writer of the essay has mentioned several countries in the previous sentence. Therefore, if more than one country is mentioned, then the writer should add 'es/s' to the word country. It becomes 'countries'. The writer also used the 'demonstrative', 'these'. 'These' are the plural form of the word 'this'. thus, the demonstrative 'these' is used with plural countable nouns.

In sentence 5, the writer of the essay omitted the plurar marker $-\mathrm{s}$ from the noun 'region'. Many is a quantifier which is used with count nouns (Azar \& Hagen, 2017; Murphy, 2019; Borjarz \& Burridge, 2010). The word 'region' is a count noun. The correct sentence should be '..so many regionshave used English..'.

\section{3) Inappropriate selection/usage of} quantifier/article determiner

Sentence 1: "Secondly, the media. The media such as website, newspaper, ... the media helps people..."

Sentence 2: " an English as a international language..."

The word 'media' is mentioned for the first time in this sentence as one of the factors why English becomes an international language and is still general. For the first appearance, the article 'the' is not required. The correct sentence should be 'secondly is media' or the writer can change a bit her sentence 'the second...(factor) component) is media such as interned, newspaper... The media (plural) help..".

4) The inappropriate combination of subject and verb.

Sentence 1"Linguistics consequences has three stands..."

Sentence 2"the importance in the Industrial revolution taking place in England" 
Sentence 3: "those makes English as the main....

Sentence 4: Many immigrants refers to..."

Sentence 5:"English is brought by James Cook in 1770", "when the colony bring prisoners at Sydney which increase the immigrations"

Sentence 6: Most of them spoken English....

Sentence 7: Here we will briefly informated about spreading English through imperialisme.

The first error, in sentence 1, has been discussed above. The focus the second error is between subject and verb agreement. The subject (noun) is 'consequences' is in plural form. It is marked by the suffix ' $-s$ '. Therefore, based on the rule of subject verb agreement that also relates to the time an action occurred, the verb should be 'have'. Verb 'have' or 'has' in this sentence has a meaning of ownership not functions as auxiliary in participle form. 'Have' deals with plural forms whereas 'has' deal with singular forms. (Murphy, 2019).

In sentence 2, a sentence must have at least a subject and a verb. The subject 'importance' needs a verb so that the verb for 'importance' could be a verb denoting a singular 'takes, is/was taking, took, has/had taken, will/shall/would/should take. However, in this sentence context the verb for 'importance' is 'took' to indicate the eventstaking place in the past. Murphy(2019) explained that verb construction depends on the tenses and noun phrase it indicates. In sentence 3 , The word 'those' functions as demonstrative pronoun. It can be either with a noun or not. It is a plural form so that suffix ' $-\mathrm{s}$ ' in the verb 'make' is unnecessary.
The sentence should be 'those make' or it is better to say 'those factors, ways, components make...' (Murphy, 2019). In sentence 4, the subject 'immigrants' is in plural form. It is indicated also by a pre-modifier, a modifier that precedes a noun, 'many'is a quantifier indicating more than one. Therefore, the verb for the noun phrase 'many immigrants' is 'have' or had depending on the tenses. In the context of that sentence, the verb for 'many immigrants' is 'had' to refer to the past action(Murphy, 2019; Azar \& Hagen, 2017; Borjarz \& Burridge, 2010).

Two errors are found in sentence 5. The first error is the context of the sentence tells us that the event is occurred in the past. It is indicated by the existence of adverb of time '1770'. It should be written in past form using simple past tense to be 'was'. The correction for this sentence is supposed to be "English was brought by James cook in 1770..."Second error is inappropriate combination of verb 'bring' with the adverb used in the sentence context which is in past form. The verb should be in simple past tense 'brought'. The reason is that the sentence tells us that the event occurred in the past. The correct sentence should be "The colony brought (the) prisoners to Sydney...". Similar error is also found in sentence 6, the verb 'spoken'indicating past participle. It should be in simple past tense 'spoke'.

In sentence 7, error is found in the verb phrase. The writer of the essay used future tense. The pattern of future tense is 's + will / shall + infinitive (present future) and $S+$ would / should + infinitive (past-future)' (Murphy, 2019). Based on the pattern, the verb that the writer used 'informated' is incorrect. After the future verb 'will', the writer must use the infinitive verb 'inform'. Thus, the correct sentence with the 
future tense pattern is 'Here we will briefly informabout spreading English through imperialisme'.

\section{Verb-Verb Group}

1) Omission of suffix -s/-es/-ed/-ing.

Sentence 1:“...on how a colonialism influence English particularly in..."

Sentence 2 :"second settlement takeplace in Virginia, in South and North"

Sentence 3: "American settlement arrivein England...."

Sentence 4 : "now English become a global language".

Sentence 5:"Canadian speak English after..."

Sentence 6:It means that the mass production had increased the flow of goods and was fostering competition; consumer purchasing power was grow.

Murphy (2019) explained that "there are all eight tenses in English. All verbs are either present or past. This combines with what grammarian call aspect. All verbs are either simple or continuous in aspect". In sentence 1, the verb 'influence' requires suffix -ed for its singular noun 'a colonialism' however the writer omitted it. If we see from the sentence context, the verb 'influence' requires suffix - ed to refer to the colonialism which happens in the past. In sentence2, there is suffix omission in the phrase 'second settlement take' if the second settlement refers to the present event, then the verb is 'takes' but if it refers to the past event, then the verb is 'took'. In sentence 3 , the error is similar to sentence 2 , verb 'arrive' needs suffix $-s$ or $-e d$ attached to it in order to denote the singular noun in the noun phrase 'American settlement'. It is 'arrives' for present event or 'arrived' for past event. Sentence 4 and sentence 5 show the same error, the adverb 'now' indicates present time so the verb become should be changed to 'becomes' (s4) and verb 'speak' (s5) should be changed to 'speaks'.

In sentence 6, the writer of the essay omitted the suffix -ing marking the progressive tense which has the form be + -ing (present participle) (Murphy, 2019). The progressive tenses give the idea that an action is in progress during a particular time. The tenses say that an action begins before, is in progress during, and continues after another time or action (Murphy, 2019). The context of the sentence is telling us about the event or action is still going on in the past. Therefore, the tense is past progressive. The past progressive describes actions or events in a time before now, which began in the past and were still going on when another event occurred (Azar \& Hagen, 2017). The correct sentence should be 'consumer purchasing power was growing'.

2) Omission of -ed participle after a form of the verb be

Sentence: ---it starts by doing ticket...

This verb phrase should be in passive form. The sentence is incorrect because the verb is written in present and not in passive form. A passive form has pattern S+tobe+pastparticiple +object (Azar \& Hagen, 2017; Murphy, 2019). Thus, 'starts' should be written 'started' and before the past participle 'started', to $b e$ 'is/was', depending on tenses and the sentence context, is placed before 'started. Therefore, the correct sentence should be 'It is started by doing ticket or it was started by doing ticket..." 
3) Inappropriate form after modal verb (unnecessary insertion/overgeneralization of suffix $-s$, -ed, -ing was not found.

The researcher found that 1) some students used the modal verb correctly in their sentences whether to express the active sentences $(S+M V+$ infinitive $)$, passive sentences $(S+M V+B e+$ past participle)or to be used with adjectives $(S+M V+b e+$ Adjective) (Azar \& Hagen, 2017; Murphy, 2019); 2) that some students did not use the modal verbs in their sentences at all.

4) Inappropriate form after modal verb (omission of suffix -ed, passive form) was not found

The passive sentences using modal verbs are written correctly by some students of English Education in their academic essays. Some of them did not use modal verbs in their essays.

5) Omission of direct object was not found.

Students did not omit the object of a sentence. Students were good enough at writing transitive verbs. Transitive verbs are verbs that can be followed by an object (Murphy, 2019).

6) Omission of infinitives 'to' was not found

Students used infinitives 'to' correctly in their sentences. They followed the rules of using infinitive to. The pattern is to + the simple form of a verb such as to see, to be, to go, etc (Azar \& Hagen (2017)) or the pattern in Murphy (2019) which is verb + to + infinitives such as decide to do, forget to do, plan to do, etc.
7) Omission of -ing participle was not found

There were no special expressions followed by -ing in essays written by students. -ing participle is also called a present participle. -ing form follows certain expressions i.e. Sam waste a lot of time watching tv, I found George using my phone (Azar \& Hagen, 2017). There are some special expression expressions in English. They are followed by -ing participle. Students of English Education wrote their academic essays with a very simple and brief English sentence.

8) Omission of auxiliary verb

Sentence 1: "...French defeated by Britain..."

Sentence 2; “...it called as Jamestown..."

Sentence 3:"..it started by doing ticket..."

Sentence 4:Caribbean, it has diverse varieties of English, impacted by political and historical factor,

"The passive voice is formed by using the appropriate tense of the verb be, followed by the past participle" (Murphy, 2019).The five sentences are passive forms. The aforementioned examples of passive sentence construction deal with the pattern of passive voice. The passive forms deal with the tenses. Those sentences denote passive forms, therefore, the auxiliary verbs, verbs used with the main verbs cannot be omitted in passive form. (Murphy, 2019). The four sentences require auxiliaries in past forms. Therefore, the correct sentences are:

1. "...French was defeated by Britain..."

2. "...it was called as Jamestown..."

3. “..it was started by doing ticket..." 
In Sentence 4, English rules do not allow us to have double subjects in a sentence without the use of conjunction. The inserted sentence above should be the complement of noun "Caribbean". Do not use subject in inserted complement. The correction is supposed to be "Caribbean, which has varieties of language, was impacted by political (noun)...".

9) Inversion of verb-subject in indirect question format was not found.

\subsubsection{Preposition Error}

1) Omission of preposition was not found

Students did not omit the prepositions. Some placed the prepositions correctly in their sentences, some were not. There were only few prepositions used by students in their essay writing.

\section{2) Unnecessary insertion of preposition}

Sentence 1: "this essay will describe shortly about the need of English..."

Sentence 2: ..this essay attempts to explore on how the journey of....

In sentence 1, preposition 'about'is one of prepositions used to introduce who or what something relates to or concerns with. However, the sentence does not require the preposition because the verb 'describe' can directly point to the object 'the need of English". Correct sentence is "this essay will describe (shortly) the need of English...

The error in the second sentence is similar to the first sentence. Preposition 'on' is not required here because it is better to point to the object directly. The correct sentenceis"this essay attempts to explore how the journey of..."
3) Inappropriate selection of usage preposition.

Sentence: "when the colony bring prisoners at Sydney which increase the immigrations".

The preposition 'at' does not fit in the context of the sentence and the preposition 'to' is more suitable. The underlying reason is the preposition 'at' is used to express 'time' and 'place' (Murphy, 2019). The verb 'bring' uses the preposition for / to. We use the preposition 'to' if to indicate the place, person, or thing that someone or something moves toward, or the direction of something.

\section{Sentence Structure}

1) Dangling modifier was not found

2) Squinting modifier was not found

\section{3) Jumbled-up or illogical sentences}

Sentence 1: “...English are used in any the condition it is caused by many factors, those factors are technological, cultural power, language dominance, and economic.

Sentence 2;“...stated that English play such roles in regulating international social and politic gathering...'

In sentence 1, the errors found are the repetition of passive forms, incorrect 'to be' and the serial words. The factors should be followed by nouns but, the writer was inconsistent with the serial words 'technological, cultural power, language dominance, and economic' The correct sentence probably could be shorten like "...English is used in any condition because of many factors such as technology, cultural power, language dominance, and economy"

Sentence 2 indicates the error which is similar to sentence 1 ; the writer was probably confused with the adjective form of the word "politic' functioning as 
adjective or noun complement for noun 'gathering' and the placement of word 'such'.The correct sentence could be"...stated that English playsan important role in regulating the social and political gathering..."

4) Incomplete or fragmented sentences was not found

5) Run-on sentence was not found

6) Inappropriate coordinating conjunction

Sentence 1: Even English is not spoken as first language in all the country, but it does not mean that....

One use of a conjunction is to connect words or phrases that have the same grammatical function in a sentence. This use of conjunctions is called "parallel structure." The conjunctions used in this pattern are and, but, or, nor. These words are called "coordinating conjunctions" (Azar \& Hagen, 2017). The writer of the essay used 'but' in her sentence however ' $b u t$ ' is unnecessary in this sentence because the sentence does not show a contradiction. Conjunction 'but' is used to show a contradiction between a sentence stated before the second statement (Azar \& Hagen, 2017).

\section{7) Inappropriate subordinating conjunction was not found}

Words that introduce adverb clauses are called "subordinating conjunctions" (Azar \& Hagen, 2017). Azar \& Hagen (2017) also listed words used to introduce adverb clauses such as if, after, before, when, while, as, as soon as, since, until, and many more. The five students with 10 essays have used four of them;if, when, after and before. They used them correctly in their sentences such as they used 'comma' to separate the independent clause and dependent clause. A comma is used if the dependent clause precedes the independent clause i.e. when we were in New York, we saw several plays.

\section{8) Inappropriate combination of conjunction}

Sentence 1: "both as native second or foreign language".

Researcher found this error only in one student's essay. The error is in paired conjuction that is both...and....this paired conjuction is the unchangeable pattern. Both is paired with and, either is paired with or and neither is paired with nor(Azar \& Hagen, 2017). The writer paired both with or. It is incorrect. Also, adding 'second'is unnecessary. It is better to directly go to the point "both as native and as foreign language'. Overall, most students can combine sentences using coordinating conjuction such as and, but, and or. Researcher did not find more of the paired conjuctions.

\section{The Major Error made by Students of English Education in Writing} Academic Essays.

\section{Noun and noun groups}

1) Unnecessary insertion of plural marker $-s$

There are 2 sentences have been found fromtwo essays written by 2 of 5 students

2) Omission of plural marker $-s$

There are 5 sentences have been found from 5 essays written by 5 of 5 students

3) Inappropriate selection/usage of quantifier/article determiner 
There are 2 sentenceshave been found from 2 essays written by 2 of 5 students

4) The inappropriation combination of subject and verb

Thereare 7 sentenceshave been found from 7 essayswritten by 5 of 5 students

\section{Verb and verb group}

1) Omission of suffix-s/-es/-ed/-ing There are 6 sentences have been found from 6 essays written by 5 of 5 students

2) Omission of -ed participle after a form of the verb be

There is only 1 sentence has been found fromone essay written by 1 of 5 students

3) In appropriate form after modal verb(unnecessary insertion/overgeneralizationof suffix $-s$, -ed, -ing was not found.

4) Inappropriate form after modal verb (omission of suffix -ed, passive form) was not found

5) Omission of direct object was not found.

6) Omission of infinitives 'to' was not found

7) Omission of -ing participle was not found

8) Omission of auxiliary verb

There are 4 sentenceshave been found from 4 essays written by 4 of 5 students

9) Inversion of verb-subject in indirect question format was not found.

\section{Preposition error}

1) Ommision of preposition
2) Unnecessary insertion of preposition

Thereare 2 sentences have been found from 2 essays written by 2 of 5 students

3) Inappropriate selection of usage preposition.

There is only 1 sentence has been found from 1 essay written by 1 of 5 students

\section{Sentence structure}

1) Dangling modifier was not found

2) Squinting modifier was not found

3) Jumbled-up or illogical sentences There are 2 sentences have been found from 2 essays written by 2 of 5 students

4) Incomplete or fragmented sentences was not found

5) Run-on sentence was not found

6) Inappropriate coordinating conjunction

There is 1 sentencehas been found from 1 essay written by 1 of 5 students

7) Inappropriate subordinating conjunction was not found

8) Inappropriate combination of conjunction

There is 1 sentence has been found from 1 essay writtenn by 1 of 5 students

From the presentation of the data above, the major errors that the students have made in 1) Noun and noun groups; students made error in the four categories and the major errors are in the fourth category that is the in appropriation combination of subject and verb consisting of 7 sentences with 
grammatical errors from 7 essays written by 5 of 5 students, and the second category that is the Omission of plural marker $-s$ consisting of 5 sentences with grammatical errors from 5 essays written by 5 of 5 students. Thus, it can be said that all the samples have made errors in these two categories. 2) Verb and verb groups; students made errors in three categories and the major categories are in the first category that is the omission of suffix-s/-es/-ed/ -ing consisting of 6 sentences with grammatical errors from 6 essays written by 5 of 5 students, and the eighth category that is the omission of auxiliary verb consisting of 4 sentences with grammatical errors from 4 essays written by 4 of 5 students. Thus, it can be said that all samples have made grammatical errors in these two categories.

\section{CONCLUSION}

Grammatical errors have been found in the essays written by the fifth semester students of English Education Study Program. The errors committed by the students are; first, noun-noun groups, this part consists of four categories, students made error in all categories. Students used unnecessary insertion of plural marker $-\mathrm{s}$, omitted the plural marker $-\mathrm{s}$, used inappropriate selection of quantifier/article determine and inappropriate combination of subject and verb. Second, verb-verb groups, this part has nine categories; students committed errors in three categories that are by omitting the suffix -s, -es, -ed, omitting -ed in participle after a form of the verb be, and omitting the auxiliary verbs.

Third, preposition error, this part has three categories. Students made errors in two categories. They made error by using unnecessary insertion of preposition and inappropriate selection of usage preposition, and the last, sentence structure, this part consists of eight categories. Students made errors in three categories by using jumbled-up or illogical sentence, using inappropriate conjunction. The major errors are committed by the fifth semester students are; first, in noun-noun groups by omitting the plural marker $-\mathrm{s}$ and using inappropriate combination of subject and verb, second, in verb-verb groups in which the errors are mainly in the omission of suffix $-\mathrm{s}$, -es, -ed and the omission of auxiliary verbs. Students of English Education still make error in their writing. Therefore, students need to improve their competence in writing an academic essay by studying much the grammar to reduce the errors. Making mistakes often happens but making error should be reduced.

\section{REFERENCES}

Adrian. 2015. An Error Analysis of EFL Students' English Writing. English Education Journal (EEJ), 6(4), 511-523.

Azar, B. S., \& Hagen, S. A. 2017. Understanding and Using English Grammar ( $\left.5^{\text {th }} E d\right)$. New York: Pearson Education, Inc.

Amara, N. 2015. Errors Correction in Foreign. Language Teaching. The Online of New Horizons in Education, 5(3), 58-68.

Booij, G. 2012. The Grammar of Words: An Introduction to Linguistic Morphology. DO10.1093/acprof:oso/9780199226 45.001.0001. 
Borjars, K., \& Burridge, K. 2010. Introducing English Grammar $\left(2^{\text {nd }} E d\right)$. Great Britain: Hodder Education.

Canie, A. 2013. Syntax: A Generative Introduction (3th Ed). United Kingdom: Blackwell Publishing.

Hamzah. 2012. An analysis of the written grammatical errors produced by freshment students in English writing. Lingua Didaktika, vol.6, no. 1: 17-25.

Imani, A. \& Habil, H. 2012. NNS postgraduate students' academic writing: Problem-solving strategies and grammatical feature. Procedia Social and Behavioural Science, vol. 66: 460-471.

Keshavars, M.H. 2012. Contrastive Analysis and Error Analysis. Tehran: Rahnama Press.

Maspufah. 2019. Grammatical error made by EFL learners Of STIBA Persada Bunda in Thesis Proposal. Lectura: Jurnal Pendidikan, 10(2), 123-135.

Mehdi, M.F. 2018. Analysis of Errors Made by First Year Secondary School Students in Writing English Sentences: A Case Study of Libyan EFL Students. International Journal of Linguistics, 10(6), 206-226.

Miles, M.B., Huberman, A.M., \& Saldana, J. 2014. Quantitative Data Analysis: A Methods Sourcebook (3th Ed). United States of America: Sage Publication, Inc.
Mohammed, S.M. 2015. Grammatical error analysis of Iraqi postgraduate students' academic writing: The case of Iraqi Students in UKM. International Journal of Education and Research, vol. 3, no. 6: 283-294.

Murphy, R. 2019. Grammar in Use (5th Ed). Cambridge: Cambridge University Press

Pratama, R.D. 2017. Indonesian EFL Teachers' Identities in Written Discourse: English or Oriental Domination. In S. Madya, F.A. Hamied, W.A. Renandya, C. Coombe, Y. Basthomi, ELT in Asia in the Digital Era: Global Citizenship and Identity, Vol.15, 361-368. Roudledge.

Putri, P.S. 2014. An Analysis of Grammatical Errors in Writing Narrative Text Done by the Second Semester Students at the Diploma Program English Department in Airlangga University Surabaya. Anglicist, 3(1), 1-7.

Yang, W. 2010. A Tentative Analysis of Errors in Language Learning and Use. Journal of Language Teaching and Research, 1(3), 266-268.

Yule, G. 2010. The Study of Language (4th ed). Cambridge: Cambridge Universiry Press.

Yule, G. 2017. The Study of Language (6th Ed). Cambridge: Cambridge University. 
Zublin, R.B. 2015. Error Correction Techniques in the EFL Class. (doctoral dissertation, Universidad FASTA, Buenos Aires). Retrieved from

http://redi.ufasta.edu.ar:8080/xmlu i/handle/123456789/877. 